[특집]

\title{
Phenomenology of Sensible Life in Husserl and Levinas
}

Nam-In Lee*

Some commentators on Levinas's phenomenology hold the view that the phenomenological movement from Husserl to Heidegger, and then from the latter to Levinas, can be described as a process of unidirectional development.1) According to this view - one that is widespread in the phenomenological world - Husserl's phenomenology was overcome by Heidegger's phenomenology, which has again been overcome by Levinas's phenomenology of the face. This view was not initiated by commentators, but by Levinas himself in some of his major works, such as Totality and Infinity ${ }^{2}$ and Otherwise than Being or Beyond Essence.3)

* Seoul National University

1) For example, A. Peperzak, "Phenomenology - Ontology - Metaphysics: Levinas's Perspective on Husserl and Heidegger," in: Man and World 16 (1983), 113-127; A. F. Beavers, Levinas beyond the Horizons of Cartesianism, Frankfurt/M.: Peter Lang, 1995.

2) E. Levinas, Totality and Infinity. Trans. Alphonso Lingis. Pittsburgh: Duquesne University Press, 1969. In this paper, this work will be referred to with the abbreviation TI.

3) E. Levinas, Otherwise than Being or Beyond Essence. Trans. Alphonso Lingis. Pittsburgh: Duquesne University Press, 1998. In this paper, this work will be referred to with the abbreviation OBBE. 
86 특지

As the title of Levinas's major work Totality and Infinity indicates, his phenomenology of the face aims at clarifying the possibility of transcendence from the plane of totality to that of infinity. Both the plane of totality and that of infinity contain many smaller planes. For example, the plane of totality contains the plane of representation, the plane of Zeug, the plane of enjoyment, etc. A plane consists of various, basically similar relations between the ego and the other. The plane of totality consists of relations between the ego and the other in which the other as a term of the relation is the other in a relative sense that can be totalized by the ego, whereas the plane of infinity consists of the relations between the ego and the other in which the other is the other in an absolute sense that cannot be totalized by the ego. It is the proper task of Levinas's phenomenology of the face to clarify the structure of the plane of infinity.

Levinas maintains that, having becn deployed on the plane of totality, the whole tradition of Western philosophy has not realized the existence of the plane of infinity, which infinitely transcends the plane of totality. He calls the whole tradition of Western philosophy ontology, and contrasts it with his phenomenology of the face as an ethics that is able to deal with the plane of infinity. According to him, the plane of infinity as the proper theme of ethics represents a realm that is more original than the plane of totality. This is the reason why he claims that "ontology presupposes metaphysics" (TI, 48) and that "preexisting the plane of ontology is the ethical plane" (TI, 201). Since ethics is presupposed by ontology, Levinas advances the thesis that ethics is first philosophy.

Although it is Husserl and Heidegger with whom Levinas attempts to discover "the existents" and thereby to found a phenomenology of the lace, for Levinas both Husserlian phenomenology and Heideggerian 
phenomenology belong to the category of ontology. Thus in Totality and Infinity, he deals with both Husserlian phenomenology and Heideggerian phenomenology as two types of ontology, each concerned with a different smaller plane within the plane of totality - namely, the plane of representation and that of Zeug. Husserl's phenomenology, which according to Levinas deals only with the plane of representation, is the most radical form of ontology, since the plane of representation consists of the relations between ego and the other in which the other is totalized by the ego in the most radical way. The phenomenology of Zeug that Heidegger developed in Sein und Zeit4) results from a criticism of Husserl's phenomenology, and from the perspective of the phenomenology of the face, it represents a more advanced position than the later. However, this does not change the basic characteristic of Heidegger's phenomenology of Zeug as a kind of ontology, since it fundamentally conceives of the existent as something whose structure is decrmined in advance by the structure of Being.

According to Levinas, both Husserlian and Heideggerian phenomenology represent preliminary stages on the way toward his phenomenology of the face as an ethics that deals with the most original realm of being. Thus in Levinas's criticism of Husserlian and Heideggerian phenomenology, one can find the same general tendency that can already be observed in Heidegger's criticism of Husserl's phenomenology. For just as Heidegger claims that Husserl's phenomenology is a mere preliminary stage or constituent moment of his own phenomenology, and moreover, one that can be integrated into the latter without reservation, Levinas in turn conceives not only of Husserlian phenomenology but also of Heideggerian phenomenology as a mere preliminary stage of his own phenomenology of the face.

1) M. Heidegger, Sein und Zeit, Tübingen: Max Niemeyer, 1972. 
In this paper, I will attempt to show that the trajectory of the phenomenological movement from Husserl to Heidegger and from the latter to Levinas cannot be described as a process of unidirectional development. In the discussion below, concentrating only on the relationship between Husserl's genetic phenomenology and Levinas's phenomenology of the face, I will attempt to show that Husserl's phenomenology is not a mere preliminary stage or constituent moment of Levinas's phenomenology of the face and that it cannot be integrated into the latter. I will demonstrate this through an analysis of the intentionality of sensible life, a theme that plays an important role both in Husserl's genetic phenomenology and Levinas's phenomenology of the face. In section 1, I will delineate some aspects of the phenomenology of sensible life developed by Levinas. In section 2, I will introduce the phenomenology of sensible life that Husserl developed as a part of genetic phenomenology, and show that Husserl's phenomenology cannot be defined as a phenomenology of representation that does not go beyond the plane of representation. Finally, in section 3, I will compare Husserl's genetic phenomenology and Levinas's phenomenology of the face, and show that they represent two basically different kinds of phenomenology that cannot be integrated into one another without reservation.

\section{Phenomenology of sensible life in Levinas's phenomenology of the face}

The phenomenology of sensible life plays a significant role in Levinas's phenomenology of the face. In Levinas' phenomenology of the face, it is introduced in order to serve as a springboard from 
phenomenology of totality as ontology to phenomenology of infinity as ethics. Levinas maintains that sensible life is not dealt with in Husserlian and Heideggerian phenomenology. A phenomenology of sensible life is therefore required in order to transcend the limitations of previous phenomenology. Due to the significance that such phenomena as sensible life and enjoyment have for a phenomenology of the face, Levinas already embarks upon analyses of these phenomena in earlier works such as Existence and Existentss) and Time and the Other.6) Then in major works such as Totality and Infinity and Otherwise than Being or Beyond Essence, Levinas deals with sensible life and enjoyment in more detail than in the earlicr works.

Sensible life is a form of life that is sustained by various kinds of sensible necds. Sensible life is distinguished from other forms of life for example, from an ethical life that is sustained by metaphysical Desire. According to Levinas, the metaphysical Desire that makes possible the relation of the ego to infinity cannot be quenched, since it is intentive to infinity as transcendence. In contrast with metaphysical Desire, however, sensible needs can be fulfilled by things in the world such as good soup, fresh air, cold water, warm sunlight, etc. In the fulfillment of sensible needs, the ego has the feeling of pleasure. Levinas calls the process of fulfilling sensible needs enjoyment. Sensible life that is sustained by sensible needs is so closely related to enjoyment that enjoyment can be called "the reality of life" (TI, 112). The various forms of sensible life such as

5) E. Levinas, Existence and Existents. Trans. Alphonso Lingis. The Hague: Martinus Niihoff, 1978. In this paper, this work will be referred to with the abbreviation EE.

6) E. Levinas, Time and the Other. Trans. R. A. Cohen. Pittsburgh: Ducuesne Zniversity Press, 1987. 
이그ㄱㅣㅣ

"living from" or on good soup, fresh air, cold water, warm weather, etc., are forms of enjoyment. In this context, enjoyment as the reality of life includes not only the states of positively enjoying something - states that are accompanied by the feeling of satisfaction and pleasure - but also the negative states of pain and suffering that result from the state of not being able to fulfill sensible needs.

As the examples of sensible life and enjoyment mentioned above show, sensible life is related to things in the world. For example, enjoyment of "living from good soup" is related to the good soup. enjoyment of "living from fresh air" is related to the fresh air, etc. Since sensible life is related to things in the world from the very beginning, it can be called a kind of intentionality. Even though Levinas criticires Husserl's concept of intentionality, he does not hesitate to talk about intentionality with respect to the structure of sensible life. As carly as Fxistence and Fxistents, for example, in context of a discussion of the structure of the "joyous appetite for things which constitutes being in the world," he writes: "The concept of intention conveys this relationship quite exactly. But it must be taken not in the neutralized and disincarnate sense in which it figures in medieval philosophy and in Husserl, but in its ordinary meaning, with the sting of desire that animates it" $(\mathrm{EE}, 37) .7)$ In contrast with the intentionality of

7) Following Levinas in this point, some commentators on his philosophy actually hold the view that Husserl's intentionality is nothing other than the intentionality "in the neutralized and disincarnated sense." Ste, for example, C. R. Vasey, "Emmanuel Ievinas: from Intentionality 1o Proximity," in: Philosophy Today (Fall 1981), 175-195; A. Peper/ak, "Phenomenology - Onkology - Metaphysics: Levinas"s Perspective on Ilusserl and Ileidegger," in: Man and World 16 (1983), 113-127; A. Cohen, Elevations. The Ileight of the Good in Rosenzweig and Levinas, Chicago and London: The University of Chicago Press, 1994; A. F. Beavers, Levinas beyond the Horizons of Cartesianism, 
representation, Levinas characterizes the intentionality of life or "the intentionality of "living from ..." (TI, 129) as "a very different "intentionality" ( $\mathrm{TI}, 126$ ), and since enjoyment is the reality of life, Levinas calls it concretely "the intentionality of enjoyment" (TI, 127).

Levinas attempts to clarify the structure of the intentionality of sensible life by comparing it with the intentionality of representation or the objectifying act, which is one of the most important topics in Husserlian phenomenology. There are many examples of the intentionality of representation, such as intentionality of perception, intentionality of imagination, intentionality of memory, intentionality of expecting, intentionality of scientific thinking, and intentionality of Wesensanschatung, to name only a ${ }_{\mathrm{c}} \mathrm{w}$. As these cxamples show, the intentionality of representation has its correlative intentional object in each case. And in normal cases, the object of the intentionality of representation is different from the act of the intentionality of representation. Due to the difference between the object and the act of the intentionality of representation, the former can be called the other of the latter. However, the object of the intentionality of representation is not the other in an absolute sense, but only in a relative sense, since it is "as it were a product of consciousness, being a 'meaning' endowed by consciousness, the result of

Frankfurt/M.: Peter Lang, 1995. However, it should be noted that, contrary to what Levinas and some commentators on him claim, Husserlian intentionality has nothing to do with the intentionality "in the neutralized and disincarnated sense," but it is rather the outcome of the criticism of the latler. I have dealt with this problem in an unpublished parer on "Crilical Review of Levinas's Criticism of Ilusserl's Concept of Intentionality." The discussion below on the problem of the intentionality of sensible life in Ilusserl will show that Ifusserl's intentionlity should not be considered to be the intentionality "in the neutralized and disincamated sense." 
(ㄴ) 특지

Sinngebung" (TI, 123). "In a sense the object of representation is indeed interior to thought: despite its independence it falls under the power of thought" (TI, 123). Levinas maintains that due to the Sinngebung, the object of the intentionality of representation is mastered by the act of the intentionality of representation. The mastery of the object by the act is so radical that the resistance of the object as an exterior being vanishes entirely. In a certain sense, there is no difference between the object and the act of the intentionality of representation. since the former is totalized and absorbed into the latter without residue. Thus the intentionality of representation is the most radical form of totalizing act. The totalizing character of the intentionality of representation can most readily be observed in the intentionality of the act of reflection, which since it has the basic structure of grasping the immanent by the immanent, that is, grasping the self by the sellknows nothing about the exterior thing from the start.

The intentionality of sensible life, however, differs radically from that of representation. The difference between them becomes clear if one thinks about the fact that "to live from bread" cannot be the same as "to represent bread to oneself." Whereas the intentionality of representation masters its intentional objects freely through its power of constitution, the intentionality of life cannot freely master its intentional object. The begimning state of the intentionality of sensible life is basically a privation or destitution that is connected with the feeling of dissatisfaction, pain, and hunger. In order to escape this state of privation and destitution, the intentionality of sensible life attempts to find the objects in the world that can satisfy it. If the intentionality of sensible life locates the object that can satisfy it, it consumes and enjoys the latter. Consuming and enjoying the 
intentional object, the intentionality of sensible life totalizes and absorbs that object. In this respect, one can say that the intentionality of sensible life has a structure that is similar to that of the intentionality of representation, and for this reason, the intentionality of sensible life forms a sub-plane of the plane of totality. Yet despite this kind of structural similarity between them, the intentionality of sensible life differs from the intentionality of representation. Due to the attempt to find the objects in the world that can satisfy it, the intentionality of sensible life displays the basic character of will, conatus, or appetite. The intentionality of life as a will, conatus, appetite is dependent on the objects in the world that can satisfy it. Sometimes the intentionality of life cannot find the objects that can satisfy it. In this case, it can experience various kinds of resistance from the side of the objects, which would make it impossible to talk about any kind of complete mastery of the intentional objects by the act of the intentionality of life. The object of the intentionality of life is not always interior to the act of that intentionality; it does not fall under the power of the latter entirely. The intentionality of sensible life consists in "holding on to the exteriority" that vanishes entirely in the case of the intentionality of representation (TI, 127). For this reason, one can say that from the perspective of exteriority, the intentionality of sensible life is more original than the intentionality of representation, and Levinas accordingly claims that enjoyment of life is "irreducible and anterior to" the knowledge provided by representation ( $\mathrm{Tl}, 130)$.

The intentionality of life as will, conatus, appetite should not be confused with Heideggerian care. As is well known, Heidegger developed the concept of care as a central concept of his phenomenology of implements through a criticism of the concept of 
representational intentionality developed in Husserl's Logical Investigations and Ideas I. According to Heidegger, care is basically a phenomenon of life from which representational intentionality is derived through a process of "Entlebung." 3 ) Care has the structure of means and end, since it is founded on "das Wornmwillen des Daseins,") that is, on the finality for the sake of which Dasein is living its life. For this reason, every individual form of life dealt with in Heidegger's phenomenology of Dasein has the structure of means and end. However, in its basic structure the intentionality of sensible life in Levinas is entirely different from Heidegger's care. To live from things in the world is not the same as to use them for some other purpose. Each instant of life is the aim itself, it cxists isolated from others. The intentionality of sensible life in Levinas does not know any kind of linality from which it can be derived. It is a pure enjoyment. "To enjoy without utility, in pure loss, gratuitously, without referring to anything else, in pure cxpenditure this is the human. There is a non-systematic accumulation of occupations and tastes ..." (TI, 133). The intentionality of sensible life knows only the instant, the today, and knows nothing about tomorrow or yesterday. The only motto that the intentionality of sensible life knows is "carpe diem." The intentionality of sensible life is characterized through "the suspension or absence of the ultimate finality" (TI, 134), that is, through "the disinterested joy of play" (TI, 134). For this reason, Levinas identifies it with the origin of all "hedonist moralities" (TI, 134).

The intentional object of the intentionality of sensible life is totally different both from the representational object and from equipment. It

8) M. Heidegger, Zur Bestimmung der Philosophie, Frankfurl/M.: Voltonio Klostermann, 1987 (Heidegger (iesamlsausgabe 56/57).

9) M. Heidegger, Sein und Zeit, 87 ff. 
does not know the distinction between substance and property that is essential to the representational object, and it is not yet embedded in the referential nexus of the world-horizon that is characteristic of implements. The object of the intentionality of sensible life is devoid of the form either of the representational object or of equipment. Thus as an entity that is devoid of such form, it camnot be called an object in a proper sense at all. Although the intentionality of sensible life is indeed directed to some entity, it does not reach it as an object or thing. What matters here is the entity anterior both to the representational object and to equipment. In fact. Levinas calls that to which the intentionality of life is directed not an object or thing, but the element as a pure quality that is anterior both to the representational object and to equipment. When we live from good soup, air, light, elc., those entities that we live from are experienced by us primarily as pure qualities such as "lasting good," "fresh," "warm," clc., not as representational objects with the distinction between substance and property or as implements that are embedded in the referential nexus of the world-horizon. The pure qualities in this case are entities that have been there long before they are experienced by us as representational objects or implements. Before these pure qualities change into implements or representational objects, they are the elements to which the intentionality of life is directed. In enjoyment or intentionality of sensible life, then, things and implements "revert to their elemental qualities" (TI, 133). The intentionality of sensible life cannot reach these elemental qualities qua representational objects or implements. For this reason, with respect to the entities to which the intentionality of life is directed. we cannot properly say that we know them or we use them, but instcad, as Levinas puts it, we are "bathing" (TI, 132) in them. 
The intentionality of sensible life has its own ego. But the ego of the intentionality of sensible life is different from a Kantian transcendental consciousness as the unity of transcendental apperception or from Heideggerian Dasein. It is anterior to them, older than they are, and has always been functioning at the bottom of the soul long before they do their job. The ego of the intentionality of sensible life is nothing other than "the body naked and indigent," as Levinas puts it in a passage from lolality and Infinity: "The body naked and indigent is the very reverting, irreducible to a thought, of representation into life, of the subjectivity that represents into life ..." (TI, 127). In this context the naked and indigent body should not be confused with the body that is experienced as one of the various constituted objects in the world. It is not the sensed, perceived, or known body. What matters here is rather the sensing body, the sentient body or the sensitive body. "Sensibility establishes a relation with a purc quality without support, with the element. Sensibility is enjoyment. The sensitive being, the body, concretizes this way of being ..." (TI, 136). The ego of the intentionality of sensible life is therefore characterized by corporeality as sensibility.

And the intentionality of sensible life correspondingly turns out to be sensitive, corporeal intentionality. An ego can never have two corporeal intentionalities with the very same contents, since corporeal intentionality changes its contents incessantly and we cannot live from the same elemental quality twice, just as no one can dip into the same river twice. This is the basic distinction between the intentionality of sensible life and the representational intentionality that can have the same content infinitely many times without this content losing its identity. Due to the uniqueness of the intentionality of sensible life, one sensible ego as the bearer of various kinds of 
intentionality of sensible life cannot be replaced by another sensible ego: since every sensible ego is always situated at a particular place on earth, enjoying the elemental qualities, it is always living from these in a unique way. Accordingly, every sensible ego is singular and does not have anything in common with other sensible egos. In a strict sense, then, there cannot be any kind of communication among different sensible egos. "In enjoyment I am absolutely for myself. Egoist without reference to the Other, I am alone without solitude, innocently egoist and alone. Not against Others, not 'as for me ...' but entirely deaf to the Other, outside of all communication and all refusal to communicate - without ears, like a hungry stomach" (TI, 134). Thus the ego of the intentionality of sensible life is characterized by egoism, "inner life" or psychism. The plane of enjoyment as a sub-plane of the plane of totality is a plane that is characterized by a plurality of sensible egos separated from each other, each isolated in its own world of elemental qualities.

\section{Phenomenology of sensible life in Husserl's genetic phenomenology}

In Totality and Infinity, Levinas maintains that Husserl's phenomenology is a phenomenology of representation and that it cannot deal with other planes beyond the plane of representation. Levinas does not deny that Husserl's phenomenology deals not only with representational intentionality, but also with non-representational intentionality, such as feeling or willing. According to him, however, this undeniable fact does not guarantee that Husserl's phenomenology can go beyond the plane of representation, since Husserl basically 
interprets non-representational intentionality in terms of representational intentionality. This is due to Husserl's underlying belief in the absolute primacy of representational intentionality against non-representational intentionality, according to which an intentional experience is either representational or is founded upon a representational experience. In this respect, sensible life is no exception: "The strictly intellectualist thesis subordinates life to representation. It maintains that in order to will it is first necessary to represent to oneself what one wills; in order to desire, represent one's goal to oneself, in order to feel, represent to oneself the object of the sentiment; and in order to act, represent to oneself what one will do" (TI, 168). The phenomenology of sensible life that was sketched above is developed by Levinas as a "converse thesis" (TI, 168) to the strictly intellectualist thesis of Husserl.

If one consults only those works of Levinas in which he draws a piclure of Husscrl as a stricl intellcclualist (c.g., Totality and Infinity and Otherwise than Being or Beyond Essence), one might easily get the impression that Husserl's phenomenology is actually limited to the plane of representation. This picture of Husserl is not surprising at all if one recalls that Husserl's phenomenology has been interpreted by many commentators in this way. Moreover, this view of Husserl is not a mere product of imagination on the part of the interpreters, but it is based on a reading of some important works that Husserl published during his lifetime, such as Logical Investigations, Ideas I, and Cartesiam Meditations. And Husserl's static phenomenology which attempts to clarify the logical structure of validity-foundation in constitution, and declares reflective consciousness to be the most original foundation of subjective validity - is indeed a kind of intellectualism. However, Levinas's portrait of Husserl's phenomenology 
as a strictly intellectualistic philosophy does not represent the whole, but only one aspect of Husserl's phenomenology.

Besides static phenomenology, Husserl attempted to develop a genetic phenomenology whose aim is to clarify the structure of genetic foundation in constitution. 16) In the order of transcendental genesis, representational intentionalities cannot come into being if the

10) The distinction between static phenomenology and genetic phenomenology as two different kinds of transcendental phenomenology is an important topic and, at the same time, a very controversial issue in Husserl's later phenomenology after 1920s. One can find Husserl's attempts to make a distinction belween them in various texts and, first of all, in the following Lexts: Hua XI, $336-345$ (English translation: "Slatic and Genelic Phenomenological Method." Trans. By A. Steinbock, in Continental Philosophy Review 31 (1998), 135-142); Ilua XIV, 34-42 (English translation: "The Phenomenology of Monadic Individuality and the Phenomenology of the General Possibilities and Compossibilities of Lived-Experiences: Static and Genetic Phenomenology." Trans. By A. Steinbock, in Continental Philosophy Review 31 (1998), 143-152); Hua XV, 613-627. I have dealt with the problem of the distinction between slatic phenomenology and genelic phenomenology in Edmund Husserls Phänomenologie der Instinkle, I)ordrechl: Kluwer Academic Publishers, 19y3, 17-30 and "Static- Phenomenokgical and (ienelic Phenomenological Concept of Primordiality in Ilusserl's Fifth Cartesian Meditation," in: Ilusserl Studies 18/3 (2002), 165-183. See also M. J. Larraboe, "Ilusserl's Static and Genetic Phenomenology," in: Man and World 9/2 (1976), 163-174; D. Welton, The Origins of Meaning. A Critical Study of the Threshold of Husserlian Phenomenology. The Hague: Martinus Nijhoff, 1983; D. Welton, "Structure and Genesis in Husserl's Phenomenology," in: Husserl: Exposilions and Appraisals. By F. A. Flliston/ P. Mc Cormick, Notre Iame: Iniversity of Notre Jame Press, 1977, 34-69; A. Steinbock, Home and Beyond Cieneraibue Phenomenology after Ilusser, Evanston, IL: Northwestem University Press, 1995; A. Steinbock, "Ilusserl's Static and Genetic Phenomenology: Translator's introduction to two Essays," in: Continental Fhilosophy Review 31 (1998), 127-131. 
100 특짐

voluntaristic moments such as instincts, drives, and willings have not already been functioning as their genetic motivation. For this reason, in the order of transcendental genesis the voluntaristic moment has an absolute primacy against representational intentionality, and genetic phenomenology turns out to be a kind of voluntarism. In fact, in a conversation with Dorion Cairns from 1931, Husserl actually affirms that he is working out a universal voluntarism.11)

It is the universal voluntarism as the basic character of Husserl's phenomenology that motivated Husserl to reinterpret the essence of intentionality and consciousness as life and to talk about the life of consciousness (Bewusstseinsleben). Correspondingly, he defines world as lifeworld (Lebenswelt), since world is ultimatcly and most fundamentally a constitutive product of life. With respect to universal voluntarism as the essence of genetic phenomenology, Husserl conceives of phenomenology not merely as a kind of philosophy of life, but as a radically new type of philosophy of life namely, as "a scientific philosophy of life,"12) as a passage from the lecture course on "Natur und Geist" from 1927 reads: "Thus the basic character of phenomenology is scientific philosophy of life, not a science assuming the foundation of already existing sciences, but a radical science that has concrete universal life and its lifeworld, the actual concrete environing world, as its original scientific theme ..."13)

11) D. Cairns, Conversations with Husserl and Fink. Ed. By R. M. Zaner, The Hague: Martinus Nijhoff, 1976, 61.

12) I have dealt with the problem of phenomenology as a scientific philosophy of life in: "Wissenschaltiche Lebensphilosophie als Grundcharakter der Phänomenologie," in: Analecta Husserliana XLVIT (1995), 25-48.

13) Natur und Geist. Vorlesungen Sommersemester 1927. Ed. Michael Weiler. Husserliana 32. Dordrecht: Kluwer Academic Publishers, 2001, 
Husserl attempts to develop genetic phenomenology as a scientific philosophy of life that would go beyond the plane of representation. Moreover, in many works and unpublished manuscripts, he engaged himself intensively with genetic analysis and developed the phenomenology of sensible life as a part of a scientific philosophy of life. Phenomenology of sensible life thereby plays a significant role in the whole system of genetic phenomenology as a scientific philosophy of life.

In order to understand the position that the phenomenology of sensible life takes in genetic phenomenology, one has to take into account the theory of various layers of life that Husserl developed with recourse to Aristolle and Leibnir., 14) According to this theory, the strcam of consciousness consists of various layers of life, each of which again consists of various kinds of life. The unitics of life on a lower layer of life serve as the foundation for the genesis of the unities of life on a higher laycr. Sensible life is situated between the layer of representational intentionality and the layer of vegetative life, which in its turn lies above the layer of material nature as the lowest form of life, life in a state of sleep. For this reason, the analysis of the structure of sensible life is essential to the clarification of the structure of the various forms of life that are genetically founded

241.

14) Husserl develops "the theory of layers of monad" (XIV, 38) with recourse to Aristolle and Leibni\%, as can be observed in the following passage from Lecture on Ethics of 1920): "Es bielel sich dann bei der Übertragung der Aristotelischen Entelechienlehre ins Transzendentale der Gedanke dar, den Leibniz unter dem Titel der 'Verworrenheit' versuchte. Das würde besagen, daß jedes unserer hyletischen Daten schon ein, Entwicklungprodulit' ist, also eine verborgene Intentionalität hat, die zuriuckverweist auf eine Synthesis (manuscript F I 21, 11). 
102 특진

upon it. Thus the theory of various layers of life does not admit any talk either about the absolute primacy of representational intentionality against other forms of intentionality, or about any kind of subordination of sensible life to representational intentionality.

Even in such works as Logical Invesigalions's) or Ideas 1,16 ) where Husserl does claim an absolute primacy of representational intentionality against non-representational intentionality, he still does not subordinate sensible life to representational intentionality. As is well known, in those works, he makes a distinction between intentional experience and non-intentional experience, and generally calls the latter sensation (Fmpfindung). But sensation in this context is nothing other than sensible life. Husserl attempts to explain the difference between them with the example of perception as a kind of intentional experience: sensation, which is situated below the layer of perception, serves as the genetic foundation for the latter. Perception as an intentional experience cannot come into being without sensations as non-intentional experiences; "they [sensations] build up the act [the intentional experience]. as necessary building blocks they make

15) E. Husserl, Logische Lintersuchungen Zweiter Band, 1. Teil. Ed. Ursula Panzer. Husseriana19/1. The Hague: Martinus Nijhoff, 1984 (below this work will be referred to with the abbrevialion XIX/1); Logical Investigaimons. Trans. J. N. Findlay. 2 vols. Iondon: Roulledge \&. Kegan Paul, 1970; Logical Investigations. Trans. J. \. Findlay. Ed. Demot Moran. 2 vols. London and New York: Routledge, 2001.

16) F. Husserl, Ideen zu einer reinen Phänomenologie und phänomenologischen Philosophie Ersies Buch Fd. Karl Schuhmann. Husserliana 3/1. The Hague: Martinus Nijhoff, 1976 (Below this work will be relerred to with the abbreviation $1 \mathrm{H} / 1$ ); Ideas Pertaining to a Pure Phenomenology and to a Fhenomenological Philosophy. First Book Trans. Fred Kersten. The Ilague: Martinus Nijholl, 1982 (Below this work will be referred to with the abbreviation Ideas I). 
possible [the coming into being of] intention ..." (XIX/1, 387; cf. Findlay trans., 559; Moran ed., vol. 2, 99). Husserl never subordinates sensible life to representational intentionality. Instead, representational intentionality is subordinated to sensible life as its genetic foundation.

Sensible life has its own intentionality. In Logical Investigations and Ideas $I$, with respect to the distinction between intentional and non-intentional experience, Husserl holds the view that sensation as sensible life is a kind of non-intentional experience. However, he eventually changes his position on this issue and admits that sensible life contains its own kind of intentionality. Even in Logical Investigations and Ideas $I$, we find contrary to expectations that his position on this issue is somewhat ambiguous. First of all, he is not confident about his definition of intentionality as "consciousness of." To our surprise, he regards intentionality as "something obviously understandable of itself and, at the same time, highly enigmatic" (IIT/1, 201; Ideas I, 212), and maintains that "it might yet be very diflicult to identify ... what originally makes up the pure essence of intentionality ..." (III/1, 191; cf. Ideas I, 202). In another passage in Ideas I, he admits that there might be some experiences that can include intentionality, even though they might lack an explicit directedness to something objective: "However, now, phenomenological reflection teaches us that this representing. thinking. evaluating directedness of the 1 ... cannot be found in every [kind of] experience, even though this experience might conceal intentionality within itself" (IIl/1, 188; cf. Ideas 1,200$) .17$. Although in the Logical Imestigations Husserl

17) With respect to the provisional character of the concept of intentionality established in Logical Investigations and Ideas I, Ifusserl writes as follows: "The concept of intentionality, apprehended in its undetermined range, as we have aprehended it, is a wholly indispensable fundamental concept which is the staring point at the 
observes that sensation is related to something outside - for example, the object that causes sensation - he is not ready to admit that sensation contains intentionality. ${ }^{18}$. However, in an appendix to Ideas II, dealing with the structure of sensation, he confesses that the sphere of sensation is "a primal sphere of intentionality, an incuthentic one "19) Husserl calls the intentionality of sensation an inauthentic or improper (uneigentich) one "since there can be no question here of a genuine 'intention toward,' for which [the participation of an active] I

beginning of phenomenology. The universality which it designates may be ever so vague prior to more precise investigalion; it may enter into an ever so great plurality of essentially different formulations; it may be ever so difficult to set forth in rigorous and clear analyses what makes up the essence of intentionality, which components of the concrete formations genuinely contain it in themselves and to which <components> it is intrinsically alienin any case, mental processes are observed from a determined and highly important point of view when we cognize them as intentive and say of them that they are consciousness of something." (II/ 1,191 ; Ideas 1,202$)$

18) A passage in Logical Investigations begins as follows: "Every sensory feeling, e.g. the pain of burning oneself or of being burnt, is no doubt after a fashion referred to an object ..." (XIX/1, 106; Findlay trans., 572; Moran ed., 109). But Husserl almost immediately adds: "Although this reference is realized in intentional experiences, no one would think of calling the sensations themselves intentional" (XIX/1, 406\% cf. Findlay trans, 573, Moran ed., 109). As the text shows, being guided by his thesis about a strict distinction between intentional and non-intentional experience, he is not ready to interpret this relation of the sensation to its object as a kind of intentionality.

19) Ideen zu einer reinen Phänomenologie und phänomenologischen Philosophie. Zneiles Buch Fd. Marly Biemel. Husserliana 4. The Irague: Martinus Nijhol,, 1952; Ideas Pertaining to a Pure Phenomenology and to a Fhenomenological Philosophy. Second Book. Trans. Richard Rojcewicz and André Schuwer. Dordrecht: Kluwer Academic Publishers, 1989. 
is needed" (IV, 335; cf. Ideas II, 347). The improper intentionality of sensation in this context is the passive intentionality that is dealt with in detail in his lectures on logic in the 1920s and in many unpublished manuscripts after that time.

As such examples as "burning oneself," "feeling pain," "touching," "seeing," and "hearing" show, the intentionality of sensible life is closely related to the body. Here the body should not be understood as a physical thing that has only physical properties such as spatiality, objective temporality, mass, etc., but as a living body that can take a stance toward things in the world. In contrast with physical things, a body can be allected by and can react to things in the world. Morcover, a body can move itself, and this bodily movement can change the process of functioning pertaining to the intentionality of sensible life. Sensation is basically motivated and guided by bodily movement, and for this reason, the intentionality of sensible life can be called kinaesthetic intentionality.

Like all the other kinds of intentionality as phenomena of life, the intentionality of sensible life is, in its beginning phase, in a state of dissatisfaction, and it strives to find a way to get satisfied. The means for finding a way to become satisfied is once again bodily movement. If the ego finds an appropriate way to satisfy the intentionality of sensible life, it will experience a positive feeling namely, a pleasure - and if this is not the case, it will experience a negative feeling, namely, pain. The feeling is another aspect of the intentionality of sensible life. With respect to feeling as an essential component of sensible life, Husserl talks about an "enjoying behavior. an enjoying of behavior" (manuscript C $16 \mathrm{IV}, 5$ ). The feeling of sensible life is not founded on representational intentionality, and it differs from the fecling that is called intentional fecling in the Logical 
106 특진

Investigations. In the language of the latter work, the feeling of sensible life would be termed non-intentional experience.

The intentionality of sensible life can carry out its own kind of constitution. since transcendental constitution is the function of intentionality. The constitution carried out by the intentionality of sensible life is not an active constitution, but a passive one, since as discussed above, the intentionality of sensible life is not an active intentionality, but a passive intentionality. Contrary to this clear fact, Levinas maintains that enjoyment has nothing to do with constitution. According to him, enjoyment as a relation of the ego to the element should not be regarded as a kind of constitution. However, Levinas's vicw is based on too narrow a concept of constitution according to which constitution always means active constitution. He does not realize that besides active constitution, there is also a passive constitution carried out by passive intentionality. The element as the object of enjoyment in which the sensible ego is "bathing" is a product of passive constitution. Without the passive constitution carried out by the intentionality of sensible life, all active constitution would be impossible.

The ego of the intentionality of sensible life is the center of passive constitution. In transcendental phenomenology, the bearer of any kind of constitution, be it an active one or a passive one, is called the transcendental ego; accordingly, the latter term can also be used for the ego of the intentionality of sensible life as the bearer of passive constitution. However, the transcendental ego as the bearer of the intentionality of sensible life should not be confused with the ego of representational intentionality as the transcendental ego of active constitution. Instead, it is a bodily ego, a corporeal ego that is devoid of representational intentionality and reflective consciousness and 
functions as the genetic foundation or the substratum of the transcendental ego of active constitution. The transcendental ego of active constitution cannot come into being if it is not founded on the transcendental ego of passive constitution. For this reason Husserl calls the transcendental ego of the intentionality of sensible life "das Vor-Ich," the pre-I,2(1)

Contrary to what Levinas maintains, Husserl's phenomenology is not limited to the plane of representation and it does not subordinate sensible life to representation. Although in major works such as Totality and Infinity and Otherwise than Being or Beyond Essence Levinas does portray Husserl's phenomenology as a phenomenology of representation, it is Levinas himself who knows very clcarly that Husserl's phenomenology gocs beyond the plane of representation and that phenomenology of representation does not represent the whole system of Husserl's phenomenology. In fact, in an article on "Intentionality and Metaphysics," published two years before Totality and Infinity, Levinas addresses Husserl's discovery of "concrete life" and its significance for his own phenomenology of the face, writing as follows: "Kantianism, in which truth does not open upon exteriority, even though it abides in the necessary, was interrupted before Heidegger substituted a metaphysical interpretation for it. Husserl was the first to free himself from Kantianism, by showing,

20) With respect to the concept of pre-I, a passage from a later manuscripl runs as follows: "Die Strukturanlayse der urtümlichen (jegenwart (das stehend lebendige Strömen) führt uns auf die Ichstruktur und die sie fundierende ständige Interschichte des ichlosen Strömens, das durch eine konsequente Ritcklrage ... aul das radikal Vor-Ichliche zurickleitet." (E. Ilusserl, Zur Phänomenologie der Intersubjektivitat. Texte aus dem Nachlab. Dritter Teil: 1929-1935, Den Haag: Martinus Nijhoff, 1973, 598) 
behind objectifying intentionality, a concrete life that is also intentional."21) This passage clearly shows that it is Husserl who enabled Levinas to see the plane of sensible life that goes beyond the plane of representation.

\section{Comparison of the phenomenology of sensible life in Husserl and Levinas}

The phenomenology of sensible life is developed by Husserl as a part of genetic phenomenology and by Levinas as a part of the phenomenology of the face. Does this fact imply that there is no difference between the phenomenology of sensible life in Husserl and in Levinas, on the one hand, and between Husserl's genetic phenomenology and Levinas's phenomenology of the face on the other? In this context, one should pay attention to the fact that genetic phenomenology and phenomenology of the face are two different types of phenomenology that are developed from two different points of view. The standpoint from which genetic phenomenology is developed is the order of transcendental genesis, whereas the standpoint from which the phenomenology of the face is developed is the order of exteriority.

The difference between genetic phenomenology and phenomenology of the face is most easily observable in the movement from phenomenology of representation to phenomenology of sensible life in both of them. In genetic phenomenology, the movement from

21) E. Levinas, Discovering Existence with Husserl. Trans.and ed. Richard A. Cohen and Michael B. Smith. Evanston, IL: Northwestern University Press, 1998, 123. 
phenomenology of representation to phenomenology of sensible life is guided by the order of transcendental genesis. From the standpoint of transcendental genesis, representational intentionality is a derivative form of intentionality, and its structure can only be explained in its structure by turning to more original forms of intentionality. The intentionality of sensible life is more original than representational intentionality and it lies beneath the layer of representational intentionality. For this reason, genetic phenomenology has to go beyond the layer of representational intentionality and arrive at the layer of sensible life.

In contrast to genetic phenomenology, in a phenomenology of the face, the movement from phenomenology of representation to phenomenology of sensible life is guided by the order of extcriority. From the standpoint of exteriority, representational intentionality is the most derivative form of intentionality, sinec it totaliyes the other in the most radical way. It is the most remote from the plane of infinity. As already mentioned, in contrast to representational intentionality, sensible life consists in "holding on to the exteriority" (TI, 127) that the representational intentionality suspends entirely. This implies that sensible life is more original than representational intentionality. And it is with the help of the correlative concepts "original-derivative" or "anterior-posterior" that Levinas does in fact develop his phenomenology of the face. With respect to the relationship between representational intentionality and sensible life, he maintains that representation is "detached from its sources," is "uprooted" (TI, 123), and enjoyment is "'anterior' to the crystallization of consciousness" ( $\mathrm{TI}, 188$ ), that is, of representational intentionality. According to him, psychism or inner life has "a still more profound structure" (TI, 54) that sustains theoretical thought as a kind of 
representational intentionality. The operative concepts that play such a significant role in the phenomenology of the face (e.g., "original-derivative," "anterior-posterior") should thus be understood not from the perspective of transcendental genesis, but exclusively from the perspective of "exteriority," as the subtitle "An Essay on Exteriority" of Totality and Infinity indicates.

The basic difference between genetic phenomenology and phenomenology of the face comes to light even more clearly if we take into account the layers that are more original than that of sensible life in both types of phenomenology. If the two types of phenomenology are basically the same, then in both of them these more original layers will turn out to be the same.

As mentioned above, in genctic phenomenology, the layer of transcendental genesis that lies beneath the layer of sensible life is the layer of vegetative life equipped with various kinds of vegetative ability such as the capability for reproduction, nourishment, or growth. The layer of vegetative life is more passive and more original than the layer of sensible life, and as such, it plays the role of a genetic foundation for the latter. From the standpoint of transcendental genesis, the layer of sensible life that is founded on the layer of vegetative life cannot come into being without the latter. Of course, as also indicated above, the layer of vegetative life is not the most original layer of transcendental genesis, i.e., one that cannot be traced back to a more original layer of transcendental genesis. In this connection it should be noted that in a manuscript, 22 ; Husserl grapples

22) See manuscript B II 2 that was written during $19(97-1908$. I have dealt with the problem of the material nature as the most original laver of transcendental genesis in "Das An-sich-Sein und die verschiedenen Gesichter der Welt," in: Phänomenologie der Natur (Fhänomenologische Forschungen Sonderband), Freiburg: Karl Alber Verlag, 1999, 91-108. 
with the possibility of conceiving of the layer of material nature as the genetic foundation for vegetative life, since vegetative life cannot come into being without being based on material nature.

In contrast to genetic phenomenology, in the phenomenology of the face the layer that is more original than the layer of sensible life is not the layer of vegetative life, but the layer of ethical life or the plane of infinity. The plane of sensible life is founded on the plane of infinity. The plane of infinity as the founding layer of sensible life consists of the relations of the ego to the Other as an other in an absolute sense that Levinas calls face. An ethical conscience accompanied by clear consciousness is essential to the relation of the ego to the other on the plane of infinity. As the bearer of the relation of the ego to the other on the plane of infinity, subjectivity cannot be something vegetative that does not have consciousness and conscience; rather, it is a subjectivity that is filled with "responsibility," "sensibility," "vulnerability," "proximity" for the Other as the other in an absolute sense (OBBE, $9 \mathrm{ff}, 61 \mathrm{ff}$ ).

Since ethical subjectivity is filled with "vulnerability" and "sensibility," Levinas regards it as a passive subjectivity and maintains that its passivity is "a passivity more passive than all passivity" (OBBE, 14; cf. OBBE, 15, 50, 55, 72). This passage might motivate one to believe that Levinas is exploring the most passive layer of life founding all the possible layers of transcendental genesis analyzed by Husserl, even the layer of material nature. Moreover, it might motivate one to believe that there cannot be any basic difference, but instead a continuity between these two types of phenomenology, so that in the end, genetic phenomenology should be replaced by a phenomenology of the face that is able to deal with the most original layer of transcendental genesis. In my view, Levinas scems to claim 
that his phenomenology is actually exploring the most passive and original layer of transcendental genesis and that it can therefore replace Husserl's genetic phenomenology.

However, one should not forget that the passivity that Levinas calls "a passivity more passive than all passivity" is not the same passivity that is at stake in genetic phenomenology. From the perspective of transcendental genesis, the ethical relation to the Other as an other in an absolute sense should not be characterized as passive, but rather as active, since it is equipped with conscience and moral consciousness. "Vulnerability" as the basic character of the ethical consciousness that Levinas calls "an inversion of the conatus of esse" (OBBE, 75) cannot be the most passive of all, since the very inversion of the conatus of esse is a genetic event that presupposes the genetic event of the conatus of esse as its genctic condition of possibility, and as an event that is more passive than the former. In ract, it should be characterized as one of the most active forms of life, since in many cases "an inversion of the conatus of esse" needs a very high degree of concentration and moral education. In his phenomenology of the face, Levinas is not exploring the most passive layer of transcendental genesis. Contrary to what Levinas seems to believe, genetic phenomenology cannot be replaced by a phenomenology of the face. Genetic phenomenology and phenomenology of the face represent two different types of phenomenology that cannot be reduced to one another.

We are now in a position to evaluate Levinas's claim that the phenomenology of the face as ethics is first philosophy. 1s ethics in the Levinasian sense really first philosophy in an absolute sense, that is, without reservation? Levinas maintains that ethics is first philosophy because it deals with the ethical relation that, in his view, 
represents the most original realm of being. However, as discussed just above, the ethical relation does not represent the most original realm of being in an absolute sense, but only in a relative sense, that is, from the standpoint of the order of exteriority. This implies that ethics in the Levinasian sense can be called first philosophy only in a relative sense, not in an absolute sense. Moreover, as long as genetic phenomenology attempts to explore the most original realm of being from a certain standpoint - namely, from the standpoint of the order of transcendental genesis - it too can be called first philosophy in a relative sense, even though Husserl himself does not call genetic phenomenology first philosophy.23) In this respect, one should pay attention to the fact that "origin" as one of the most important philosophical terms can be understood in many different senses, as Aristolle points out in the first chapter of the Fifth Book of his Metaphysics. ${ }^{24)}$ Sinec both genetic phenomenology and phenomenology of the face deal with the "origin" in a certain sense, they can claim to be first philosophy only in a relative sense, but not in an absolute sense. We finite human beings cannot conceive a first philosophy in

23) For Husserl, first philosophy is not genetic phenomenology, but the critique of knowledge (die Frkenntniskritik) that is, in my view, an important part of slatic phenomenology. See his Lecture on First Philosophy from 1923/24 (Husserliana vol. 17ll. Needless to say, so long as the critique of knowledge has its own inalienable right, there is a good sense in which it can be called lirst philosophy. For this reason, Levinas's criticism of Ilusserl's transcendental phenomenology as a phenomenology of representation should be critically assessed. since, from the standpoint of validity foundation, the self-consciousness as a kind of representational intentionality has an absolute priority against the other kinds of intentionality and should not be considered to be a derivalive fom of intentionality, as Ievinas supposes it to be.

21) Aristotle, Metaphysics, $1012 \mathrm{~b}-1013 \mathrm{a}$. 


\section{4 특짐}

an absolute sense. This might be the reason why in the long tradition of the history of philosophy there have been various concepts of first philosophy that differ from each other. How many different ways we can talk about the concept of "origin," how many different concepts of first philosophy are possible, and how they belong together these are issues that go beyond the scope of this paper.

The basic difference between genetic phenomenology and phenomenology of the face is reflected in the phenomenology of sensible life as a part of the former and of the latter. Phenomenology of sensible life as a part of genetic phenomenology is not the same as phenomenology of sensible life as a part of the phenomenology of the face. Rather and this has to be explicitly recognized they deal with different aspects of sensible life. In genetic phenomenology, sensible life is analyzed with respect to its function of transcendental genesis, whereas in phenomenology of the face, it is analyred with respect to the structure of exteriority contained in it. Phenomenology of sensible life as a part of constitutive phenomenology and as a part of phenomenology of the face represent two basically different ways in which to investigate sensible life systematically. ${ }^{25}$ )

As discussed above, genetic phenomenology is a kind of philosophy of life that has phenomenology of sensible life as one of its essential constituents. As discussed on other occasions, ${ }^{26}$ ) in Husserl, genetic

23) Needless to say, the difference between genetic phenomenology and phenomenology of the lace can also be detected in the phenomenology of representational intentionality as a part of the former and of the latter. In genetic phenomenology, representational intentionality is analyzed with respect to the problem of transcendental genesis, whereas in phenomenology of the face, it is investigated with respect to the problem of exteriorily.

26) Nam-In Lee, "T-nterschiedliche Problemfelder einer Phänomenologie 
phenomenology as a philosophy of life culminates in philosophy of nature and phenomenological metaphysics. In a similar way, a phenomenology of the face that has the phenomenology of sensible life as one of its essential constituents can also be viewed as a kind of philosophy of life. Phenomenology of the face as a kind of phenomenology of life culminates in phenomenology of infinity as a phenomenology of ethical life. It should therefore be recognized that genetic phenomenology and phenomenology of the face as two basically different types of phenomenology of life do not contradict one another. Rather, they could cooperate to deal with some of the problems that we are now facing in the age of environmental crisis. And above all, they could cooperate to cope with the critical situation of a world where science and technology have prevailed to such an extent that life in general is extremely threatened in its existence.

der Intersubjektivität," in: Kahı Kyung Cho and Jeon Sook Irahn (ed.) Phänomenologie in Korea, Freiburg: Karl Alber Verlag, 2001, 69 ff. 